\author{
FINAL REPORT \\ U.S. Department of Energy
}

\title{
UTILIZATION OF KINETIC ISOTOPE EFFECTS FOR THE CONCENTRATION OF TRITIUM
}

Principal Investigator: Gilbert M. Brown

Institution: Oak Ridge National Laboratory

Co-Principal Investigator: Thomas J. Meyer ${ }^{*}$

Institution: University of North Carolina at Chapel Hill

Collaborators: C.-H. Ho, Leon Maya, and Frederick V. Sloop, Jr. Institution: Oak Ridge National Laboratory

Collaborators: Poonam M. Narula and My Hang V. Huynh, Institution: University of North Carolina

Project Number: EMSP No. 55103

Grant Number: TTP No. OR17SP22 3TFW

Project Duration: September 1, 1996 to January 1, 2001

\footnotetext{
* Current Address: Thomas J. Meyer, Associate Laboratory Director, Strategic and Supporting Research Directorate, Los Alamos National Laboratory, Los Alamos, NM 87545
} 


\section{Table of Contents}

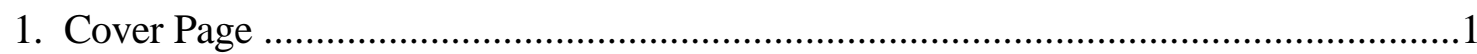

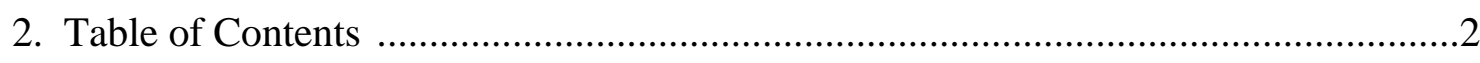

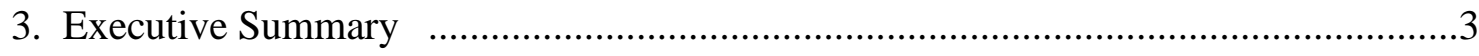

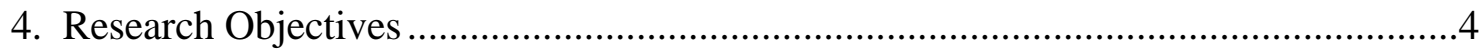

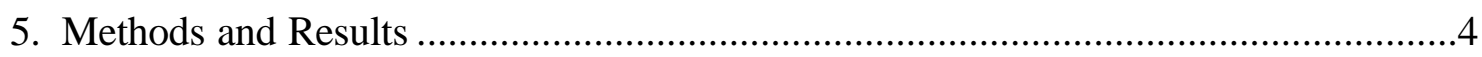

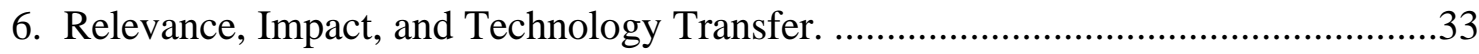

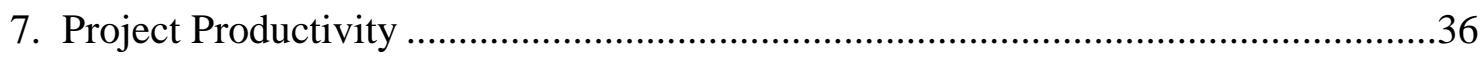

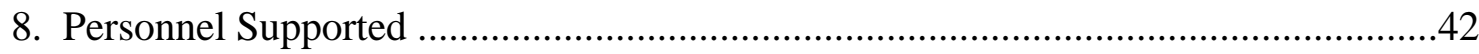

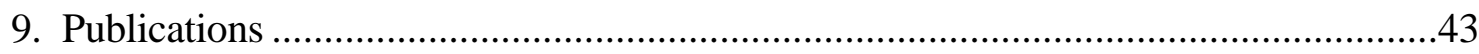

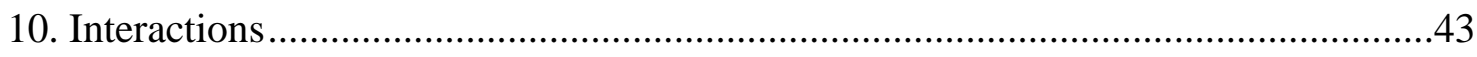

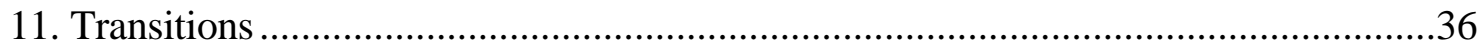

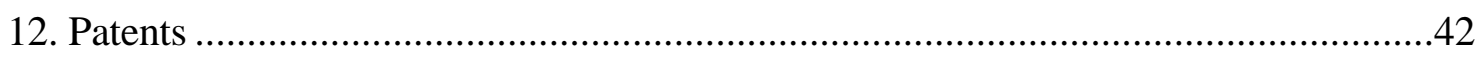

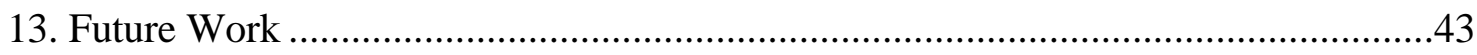

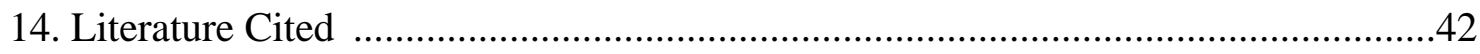




\section{Executive Summary}

The objective of this project was to develop methods for concentrating tritium in water based on large primary isotope effects in catalytic redox processes. Research was conducted to develop a process to remove tritium from $\mathrm{H}_{2} \mathrm{O}$ by concentrating it with respect to protio-water that could be employed on a variety of scales to address DOE's tritium contamination problems. Chemical cycles were investigated that produce high concentration factors for $\mathrm{HTO}$ and $\mathrm{T}_{2} \mathrm{O}$ based on the discrimination of $\mathrm{C}-\mathrm{H}$ and $\mathrm{C}-\mathrm{T}$ bonds in oxidation reactions. $\mathrm{H}-\mathrm{T}$ discrimination occurs as the tritium containing compound is oxidized in a step involving a transition metal oxidant. Strong primary kinetic isotope effects lead to the oxidation of $\mathrm{C}-\mathrm{H}$ bonds in preference to $\mathrm{C}$ - $\mathrm{T}$ bonds, and this reaction leads to concentration of tritium in the organic compound. The process is designed so that the reduced form of the transition metal compound can be electrochemically reoxidized so that the oxidation step can be made catalytic.

Proof of principal was demonstrated for the elements of a catalytic cycle with deuterium. The electrochemical reduction of carbon dioxide in an aqueous solution containing $\mathrm{D}_{2} \mathrm{O}$ demonstrated the incorporation of deuterium in the formate anion product. A cyclic process in which the reduction of $\mathrm{CO}_{2}$ is coupled to the $\mathrm{Ru}(\mathrm{IV})$ catalyzed oxidation of the formate anion is suggested. The fractionation of the deuterated component in a mixture of proteo- and deuteroformate was demonstrated using a soluble $\mathrm{Ru}(\mathrm{IV})$ oxo complex as a catalyst. The $\mathrm{Ru}(\mathrm{IV})$ oxo species chosen for this work was the complex $[\mathrm{Ru}(\mathrm{IV})(\mathrm{terpy})(\mathrm{bpy}) \mathrm{O}]^{2+}$ where terpy is $2,2^{\prime}, 2^{\prime}$ 'terpyridine and bpy is 2,2'-bipyridine. We have determined the tritium kinetic isotope effect $\left(\mathrm{k}_{\mathrm{H}} / \mathrm{k}_{\mathrm{T}}\right)$ for oxidation of formate by the complex $\left[\mathrm{Ru}(\mathrm{IV})(\text { terpy)(bpy)O }]^{2+}\right.$. The rate constant for for oxidation of tritiated formate anion was determined at a tracer level by measuring the rate of transfer of tritium from the formate anion to water following oxidation. The rate constants for oxidation of the protio- and deutero-formate were determined using entirely protio or deutero substrates. The tritium kinetic isotope effect, $\mathrm{k}(\mathrm{H}) / \mathrm{k}(\mathrm{T})$, was observed to be dependent on ionic strength, and at $\mu 0.1 \mathrm{M}$ and $25 \mathrm{C}$, the rate constant ration was observed to be in excess of 300 . This result has both scientific and technological significance. From a scientific point of view, this is the largest kinetic isotope effect observed at ambient temperatures, and it demonstrates the importance of nuclear tunneling in the hydride transfer mechanism. The technological significance is that tritium and protium can be separated in a single stage based on this large rate 
ratio. We have begun to develop the catalytic chemistry in redox active films and membranes on electrode surfaces, configurations that might be appropriate for device applications.

A second general theme is to evaluate $\mathrm{C}-\mathrm{H} / \mathrm{C}-\mathrm{T}$ kinetic isotope effects in the oxidation of several functionally different organic substrates by $\mathrm{Ru}(\mathrm{IV})$ oxo complexes. The oxidation of benzyl alcohol derivatives might lead to a practical application of this chemistry more rapidly than a system based on carbon dioxide and formate. Chemistry based on osmium complexes has the potential for even large isotope effects. The development of a closed cycle bench scale system to concentrate tritium from groundwater was not experimentally realized and will require additional funding.

One of the benefits of this method of tritium separation is that the tritium is incorporated in a substrate that does not exchange rapidly with water. Highly concentrated tritium in water is an extreme health hazard because of the ready exchange with normal isotopic composition water, and an accidental release of highly enriched water is a great hazard. If ion exchange is used to separate the tritiated substrate from solution, the process will incorporate the tritium in a matrix that will prevent the ready transport of the tritium in groundwater as well as making it safer for workers to handle. 


\section{Research Objectives}

The objective of this project was the development of methods for concentrating tritium in water based on large primary isotope effects in catalytic redox processes. Basic research was conducted to develop the chemistry of a complete cyclic process. The general methodology developed in this work will be applicable to a number of DOE waste streams, and as a consequence of the process tritium could be incorporated in an organic polymer or other solid waste form which will prevent its ready transport in ground water. The research was aimed at developing chemical cycles that produce high concentration factors for $\mathrm{HTO}$ and $\mathrm{T}_{2} \mathrm{O}$. $\mathrm{H}-\mathrm{T}$ discrimination occurs in an oxidation step involving a transition metal oxidant and small organic compounds containing oxidizable $\mathrm{C}-\mathrm{H}$ or $\mathrm{C}-\mathrm{T}$ bonds. Strong primary kinetic isotope effects lead to preferential oxidation of $\mathrm{C}-\mathrm{H}$ bonds whose products are readily removed from the unreacted $\mathrm{C}-\mathrm{T}$ compound. Since the reduced transition metal oxidant may be easily regenerated in an electrochemical reaction, the oxidation of the organic substrate becomes catalytic. On the other side of the cycle, tritium in the form of $\mathrm{HTO}$ and $\mathrm{T}_{2} \mathrm{O}$ is incorporated into the oxidized organic substrate in a reductive process, and thus the chemical cycle may be closed.

\section{Methods and Results}

The baseline technology for tritium separation from ground water takea advantage of technology developed for the enrichment of deuterium from water. ${ }^{1}$ Tritium separation technology and tritium mitigation techniques are reviewed biennially as applied to Hanford wastewater as mandated by the Hanford Federal Facility Agreement and Concent Order. Reports were issued in $1995^{2}, 1997^{3}$, and $1999^{4}$ Fulbright, et al ${ }^{5}$ have reviewed the available technology for the removal of tritium from water (or mitigation) with respect to the needs at DOE's Savannah River site. Among the processes that have been use to separate isotopes of hydrogen are water distillation (usually conducted at reduced pressure), hydrogen distillation (cryodistillation of $\mathrm{H}_{2}$ and isotopic mixtures), water electrolysis, chemical exchange processes, and combinations of the aforementioned processes. The most economical processes for isotope recovery are those that take advantage of chemical exchange between water and either hydrogen gas, hydrogen sulfide, or ammonia. Enrichment factors per stage via these processes are based on thermodynamic rather than kinetic factors. Fulbright, et $\mathrm{al}^{5}$ concluded that the Girdler sulfide process should be the most economical process for recovery of tritium from groundwater. This process uses exchange between hydrogen sulfide and water, and it takes advantage of the temperature difference in equilibrium constants for the exchange between protio-water and deuterated hydrogen sulfide, with deuterated hydrogen sulfide being favored at higher temperatures. Water flows downward through a cold tower into a heated tower counter-current to a stream of hydrogen sulfide. Water becomes enriched in the higher mass isotope as it goes through the cold tower and depleted in the isotope of higher mass as it goes through the hotter 
tower. The Canadian nuclear industry (Chalk River Nuclear Laboratories) has developed a process for tritium removal from contaminated reactor coolant water using the catalyzed exchange between hydrogen and water in the liquid phase (Liquid Phase Catalytic Exchange). This process requires a wetproof catalyst, probably consisting of Pd on carbon with a Teflon coating to keep it hydrophobic, which is used to accelerate the exchange between tritiated water and hydrogen. Enrichment of tritium in elemental hydrogen is then accomplished by cryogenic distillation. Counter-current flow of hydrogen and water in a column results in separation of the tritium. The process requires elemental hydrogen $\left(\mathrm{H}_{2}\right)$ that is produced by electrolysis of tritiated water. Water electrolysis, with separation of isotopes during or following the electrolysis process, followed by recombination of the $\mathrm{H}_{2}$ with $\mathrm{O}_{2}$ to form pure water may be a solution to the problem with current technology, but it would be power intensive and very expensive. Significant separation factors $(H / T)$ in the range of 7 to 29 were observed for the concentration of tritium by electrolysis of tritiated water. Combined electrolysis-liquid phase catalytic exchange methods were developed in the early 1970 s to separate tritium from $\mathrm{D}_{2} \mathrm{O}$ in the heavy water moderated CANDU reactors.

Both the Girdler -Sulfide process and the liquid phase catalytic exchange process described above have been efficiently carried out on a large scale. Under those circumstances a high enrichment factor per stage is of lesser importance compared to the energy costs to operate the plant and the capital cost for construction. The scheme for separation of tritium from ground water considered by this project will achieve a large separation factor in each stage and will have the benefit of allowing the same technology to be practical for both small scale and large scale remediation projects. The proposed scheme will take advantage of a relatively large kinetic isotope effect $\left(\mathrm{k}_{\mathrm{H}} / \mathrm{k}_{\mathrm{T}}>300\right)$ which will allow a single stage to achieve a relatively high tritium decontamination factor. The same technology that is implemented in a reasonably large throughput facility to decontaminate a contaminated aquifer could be incorporated in a truckmounted or skid-mounted unit for temporary use in cleaning up a contaminated well, pond, or storage tank. As a consequence of the process, the tritium will be incorporated in a medium that slowly exchanges with water. This reduces the risk to the personnel involved as well as to the environment.

Background Chemistry. In previous work by Meyer and coworkers, a wide variety of redox mechanisms have been established for the oxidants $c i s-\left[\mathrm{Ru}^{\mathrm{IV}}(\mathrm{bpy})_{2}(\mathrm{py})(\mathrm{O})\right]^{2+}(\mathrm{py}=$ pyridine, bpy $=2,2^{\prime}$-bipyridine $)$ and $\left[\mathrm{Ru}^{\mathrm{IV}}(\mathrm{tpy})(\mathrm{bpy})(\mathrm{O})\right]^{2+}$ (tpy $=2,2^{\prime}: 6^{\prime}, 2^{\prime \prime}$-terpyridine) based on kinetics, $\mathrm{H} / \mathrm{D}$ kinetic isotope effects, ${ }^{18} \mathrm{O}$ labeling, electrochemistry, spectral changes, and isolation of intermediates. Examples include: oxygen atom transfer in the oxidations of $\mathrm{PPh}_{3},{ }^{6} \mathrm{SMe}_{2}$ and $\mathrm{OSMe}_{2} ;{ }^{7}$ hydride transfer in the oxidations of benzyl alcohol, ${ }^{8}$ and formate anion $\left(\mathrm{HCO}_{2}^{-}\right) ;{ }^{9}$ and proton-coupled electron transfer (H-atom transfer) in the oxidations of hydrogen peroxide, ${ }^{10}$ and hydroquinone. ${ }^{11}$ Parallel studies have been conducted by Takeuchi et alia based on cis- 
$\left[\mathrm{Ru}(\mathrm{bpy})_{2}\left(\mathrm{PR}_{3}\right)(\mathrm{O})\right]^{2+}$ (for $\mathrm{R}=n$-alkyl, phenyl), ${ }^{12}$ and by Che et alia based on $\mathrm{Ru}(\mathrm{IV})$ oxo and $\mathrm{Ru}(\mathrm{VI})$ dioxos with porphyrin and macrocyclic ligands. ${ }^{13}$

Solvent Isotope Effects. A remarkable feature of the $\mathrm{Ru}(\mathrm{IV})$ oxidants is the observation of large H/D kinetic isotope effects for reactions with substrates that contain dissociable protons. The comproportionation reaction (1), for example, displays a kinetic isotope effect, $k_{\mathrm{H}_{2}} \mathrm{O} / k_{\mathrm{D}_{2} \mathrm{O}}$ $=16.1 \pm 0.3$ over a wide $\mathrm{pH}$ range $(2<\mathrm{pH}<9)$, where $K_{\mathrm{com}}=72\left(\Delta G^{\circ}=0.11 \mathrm{~V}\right)$ in both $\mathrm{H}_{2} \mathrm{O}$ and $\mathrm{D}_{2} \mathrm{O}$ at $25^{\circ} \mathrm{C} .{ }^{14}$

$\left[\mathrm{Ru}^{\mathrm{IV}}(\mathrm{bpy})_{2}(\mathrm{py})(\mathrm{O})\right]^{2+}+\left[\mathrm{Ru}^{\mathrm{II}}(\mathrm{bpy})_{2}(\mathrm{py})\left(\mathrm{OH}_{2}\right)\right]^{2+} \rightleftharpoons 2\left[\mathrm{Ru}^{\mathrm{III}}(\mathrm{bpy})_{2}(\mathrm{py})(\mathrm{OH})\right]^{2+}$

The mechanism for the comproportionation reaction is thought to be simultaneous $\mathrm{H}^{+} / \mathrm{e}^{-}$ transfer:

$$
\mathrm{Ru}^{\mathrm{IV}}=\mathrm{O}^{2+}+\mathrm{Ru}^{\mathrm{II}}-\mathrm{OH}_{2}{ }^{2+} \longrightarrow \mathrm{Ru}^{\mathrm{III}}-\mathrm{OH}^{2+}+\mathrm{Ru}^{\mathrm{III}}-\mathrm{OH}^{2+}
$$

Other pathways can be ruled out on thermodynamic and kinetic grounds. The large $k_{\mathrm{H}_{2}} \mathrm{O}^{/} k_{\mathrm{D}_{2} \mathrm{O}}$ isotope effect points to the likelihood of a synchronous mechanism involving simultaneous transfer of both a proton and an electron from $\mathrm{Ru}^{\mathrm{II}}-\mathrm{OH}_{2}{ }^{2+}$ to $\mathrm{Ru}^{\mathrm{IV}}=\mathrm{O}^{2+}$. Similar behavior was observed for the oxidations of hydrogen peroxide $\left(k_{\mathrm{H}_{2}} \mathrm{O} / k_{\mathrm{D}_{2} \mathrm{O}}=21.6 \pm 1.2, \mathrm{pH} 2.3\right)$, and hydroquinone, $\left(k_{\mathrm{H}_{2}} \mathrm{O} / k_{\mathrm{D}_{2} \mathrm{O}}=28.7 \pm 1.0, \mathrm{pH} 4.45\right)$ by $\left[\mathrm{Ru}^{\mathrm{IV}}(\mathrm{bpy})_{2}(\mathrm{py})(\mathrm{O})\right]^{2+}$ at $25{ }^{\circ} \mathrm{C}$. In both cases, the conjugate base forms of the substrates displayed much smaller solvent isotope effects.

Substrate Isotope Effects. Large H/D kinetic isotope effects were also observed for substrates with non-dissociable protons. For example, the oxidations of alcohols displayed $k_{\mathrm{CH}} / k_{\mathrm{CD}}$ kinetic isotope effects that ranged from 9 for methanol to 50 for benzyl alcohol, as shown in (2), without any significant $\mathrm{H}_{2} \mathrm{O} / \mathrm{D}_{2} \mathrm{O}$ solvent isotope effect. ${ }^{15}$

$\left[\mathrm{Ru}^{\mathrm{IV}}(\text { bpy })_{2}(\mathrm{py})(\mathrm{O})\right]^{2+}+\mathrm{Ph}-\mathrm{CH}_{2}-\mathrm{OH} \longrightarrow\left[\mathrm{Ru}_{(\mathrm{I}} \mathrm{Ilpy}_{2}(\mathrm{py})\left(\mathrm{OH}_{2}\right)\right]^{2+}+\mathrm{Ph}-\mathrm{CHO}$

Furthermore, we have shown that such reactions can be made electrocatalytic by use of controlled potential electrolysis to replenish the $\mathrm{Ru} \mathrm{IV}_{=}=\mathrm{O}^{2+}$ oxidant, with liberation of $\mathrm{H}_{2}(\mathrm{~g})$ at the counter electrode. ${ }^{16}$ A similar observation was made for oxidation of formate anion, as shown in (3), where $k_{\mathrm{CH}} / k_{\mathrm{CD}}=19 \pm 3$ and $k_{\mathrm{H}_{2}} \mathrm{O}^{/ k} \mathrm{D}_{2} \mathrm{O}=0.96$ at $\mathrm{pH} 7,25^{\circ} \mathrm{C}^{17}$ The corresponding reaction with formic acid $\left(\mathrm{p} K_{\mathrm{a}}=3.75\right)$ was found to be very slow $\left(k=0.01 \pm 0.04 \mathrm{M}^{-1} \mathrm{~s}^{-1}\right)$, or perhaps even non-spontaneous.

$\left[\mathrm{Ru}^{\mathrm{IV}}(\text { bpy })_{2}(\mathrm{py})(\mathrm{O})\right]^{2+}+\mathrm{HCO}_{2}^{-}+\mathrm{H}_{2} \mathrm{O} \longrightarrow\left[\mathrm{Ru}^{\mathrm{II}}(\mathrm{bpy})_{2}(\mathrm{py})\left(\mathrm{OH}_{2}\right)\right]^{2+}+\mathrm{CO}_{2}\left(\mathrm{~g}^{2}\right)+\mathrm{OH}^{-}(3)$ 
This fundamental chemistry has important technology implications because it creates a systematic basis for separating the isotopes of $\mathrm{H}$ by using well-known concepts in electrochemical technology.

This research involves the development of a chemical cycle that produces high concentration factors for $\mathrm{HTO}$ and $\mathrm{T}_{2} \mathrm{O}$ based on the discrimination of $\mathrm{C}-\mathrm{H}$ and $\mathrm{C}-\mathrm{T}$ bonds in an oxidation reaction. Several steps are required in a cyclic process for the concentration of tritium in water. In the first step the tritium is incorporated in an organic compound. H-T discrimination occurs as the tritium containing compound is oxidized in a step involving a $\mathrm{Ru}(\mathrm{IV})$ oxo complex. Strong primary kinetic isotope effects lead to the oxidation of $\mathrm{C}-\mathrm{H}$ bonds in preference to $\mathrm{C}-\mathrm{T}$ bonds, and this reaction leads to concentration of tritium in the organic compound. The reduced form of the ruthenium compound can be reoxidized so that the oxidation step can be made catalytic.

Great progress has been made toward demonstrating the individual steps required for the concentration of tritium in water. An early research objective was to carry out a proof-ofprinciple "cold" experiment in which the electrochemical reduction of carbon dioxide in an aqueous solution containing deuterium shows the incorporation of deuterium in the formate anion product. This was coupled to the catalytic oxidation of the formate anion demonstrating the fractionation of the deuterated component in a mixture of protio- vs. deutero-organic compounds. The Ru(IV) oxo species chosen for this work was the complex $\left[\mathrm{Ru}(\mathrm{IV})(\text { terpy)(bpy)O }]^{2+}\right.$ where terpy is 2,2',2''-terpyridine and bpy is 2,2'-bipyridine. We have determined the tritium kinetic isotope effect $\left(\mathrm{k}_{\mathrm{H}} / \mathrm{k}_{\mathrm{D}}\right)$ for oxidation of formate by the complex $\left[\mathrm{Ru}(\mathrm{IV})(\text { terpy)(bpy)O }]^{2+}\right.$. In terms of more long range goals, progress has been made in additional areas. We have begun to develop the catalytic chemistry in redox active films and membranes on the electrode surface, configurations that might be appropriate for device applications. The second general theme is to evaluate $\mathrm{C}-\mathrm{H} / \mathrm{C}-\mathrm{T}$ kinetic isotope effects in the oxidation of several functionally different organic substrates by $\mathrm{Ru}(\mathrm{IV})$ oxo complexes. The oxidation of mono-deutero-benzyl alcohol revealed a small kinetic isotope effect, indicating that potential substrates for tritium isotope effects can only have a single site. An investigation of the chemistry of related high oxidation state osmium terpyridyl complexes has been rewarding. Oxo-like reactivity was observed for high oxidation state osmium hydrazido complexes. The proton-coupled electron transfer reaction of an osmium hydrazido complex was observed to have a N-H/N-D kinetic isotope effect of 41.4. These reactions may have significance for devising more effective catalyst-organic substrate combinations.

Tritium Isotope Effect for Oxidation of Formate. The deuterium and tritium kinetic isotope effects for the oxidation of formate anion to carbon dioxide with $[\mathrm{Ru}(\mathrm{IV})(\mathrm{terpy})(\mathrm{bpy}) \mathrm{O}]^{2+}$ were measured. The kinetics of the deutero and protio-formate were carried out with formate as the reagent in excess, and the rate determining step was oxidation of formate to $\mathrm{CO}_{2}$ and reduction of $\mathrm{Ru}(\mathrm{IV})$ to $\mathrm{Ru}(\mathrm{II})$ by hydride transfer. The deuterium kinetic isotope effect $(\mathrm{k}(\mathrm{C}-\mathrm{H}) / \mathrm{k}(\mathrm{C}-\mathrm{D}))$ 
for oxidation of formate by $\left[\mathrm{Ru}(\mathrm{IV})(\text { terpy)(bpy)O }]^{2+}\right.$ was observed to be 38 which is a factor of two larger than the ratio measured by Roecker and Meyer $\left(\mathrm{k}_{\mathrm{H}} / \mathrm{k}_{\mathrm{D}}=19\right)$. The value of the rate constant for oxidation of protio-formate was $9.45 \mathrm{M}^{-1} \mathrm{~s}^{-1}$ which is more than a factor of two larger than the value reported by Roecker and Meyer for oxidation of formate by $\left[\mathrm{Ru}(\mathrm{IV})(\mathrm{bpy})_{2}(\mathrm{py}) \mathrm{O}\right]^{2+}\left(4.2 \mathrm{M}^{-1} \mathrm{~s}^{-1}\right)$. [Ru(IV)(terpy)(bpy)O $]^{2+}$ is a stronger oxidizing agent than $\left[\mathrm{Ru}(\mathrm{IV})(\mathrm{bpy})_{2}(\mathrm{py}) \mathrm{O}\right]^{2+}$ and that the rate constant would be higher is expected on that basis alone. We have examined the ionic strength dependence of the reaction in some detail, and to our surprise the reaction of the protio-formate was found to have a stronger dependence than the rate of oxidation of the deutero-substrate.

Measurement of the kinetic isotope effect for oxidation of tritiated formate anion was made at the tracer level by measuring the rate of transfer of tritium from the formate anion to HTO. The deuterium kinetics employed a fully deuterated substrate, but that level of tritium is too high to handle with resorting to a hot cell. Thus the experimental constraints dictated that the reagent in excess be $\mathrm{Ru}(\mathrm{IV})$. This limitation did simplify the analysis because in the presence of the large excess of $\mathrm{Ru}(\mathrm{IV})$, the only observed product is $\mathrm{Ru}(\mathrm{III})$. The absence of an excess of formate removes the complication of $\mathrm{Ru}(\mathrm{III})$ reaction with that substrate. However, this change presented other complications in data analysis.

The tritium kinetics were determined as a batch process with analysis of the reaction mixture as a function of time. The formate was 7\% labeled with a tritium. An aliquot was removed, diluted, and passed through ion exchange resins to remove the Ru complexes and the unreacted formate. The water passing through the column was assayed for tritium using scintillation counting to determine the reaction rate. An extradordinary result of this study is the magnitude of the tritium isotope effect $\left(\mathrm{k}_{\mathrm{H}} / \mathrm{k}_{\mathrm{T}}=305\right)$. This appears to be the largest kinetic isotope effect ever measured at room temperature. ${ }^{18}$ A summary of the C-H/C-D, C-H/C-T, and $\mathrm{C}-\mathrm{D} / \mathrm{C}-\mathrm{T}$ kinetic isotope effects is given below.

$$
\begin{array}{ll}
\mathrm{k}\left(\mathrm{HCO}_{2}^{-}\right)=9.45 \mathrm{M}^{-1} \mathrm{~s}^{-1} & \mathrm{k}(\mathrm{H}) / \mathrm{k}(\mathrm{D})=38 \\
\mathrm{k}\left(\mathrm{DCO}_{2}^{-}\right)=0.25 \mathrm{M}^{-1} \mathrm{~s}^{-1} & \mathrm{k}(\mathrm{D}) / \mathrm{k}(\mathrm{T})=8.1 \\
\mathrm{k}\left(\mathrm{TCO}_{2}{ }^{-}\right)=0.031 \mathrm{M}^{-1} \mathrm{~s}^{-1} & \mathrm{k}(\mathrm{H}) / \mathrm{k}(\mathrm{T})=305
\end{array}
$$

There are various theoretical formulations of kinetic isotope effects. The classical relationship between protium/deuterium and protium/tritium isotope effects is given by the equation of Swain, et al ${ }^{19}$

$$
\mathrm{k}_{\mathrm{H}} / \mathrm{k}_{\mathrm{T}}=\left(\mathrm{k}_{\mathrm{H}} / \mathrm{k}_{\mathrm{D}}\right)^{1.442}(38)^{1.442}=190
$$

This relationship was derived from the harmonic oscillator model for breaking an $\mathrm{X}-\mathrm{H}$ bond where $\mathrm{X}$ is a heavy isotope compared to $\mathrm{H}$. Thus the molecules are assumed to differ only in zero-point vibrational energy; and it is assumed that all molecules pass over the barrier. The 
magnitude of the tritium isotope effect observed here can only be explained by a quantum approach and nuclear tunneling.

An energy coordinate diagram is shown in Figure 1 which illustrates both classical barrier crossing and $\mathrm{C}-\mathrm{H}$ tunneling transitions through the barrier. Tunneling transitions dominate because of a high energy barrier crossing. They depend on the tunneling distance, the separation between energy surfaces, and the zero point energies. It is the latter that dictates the relative magnitudes of the $\mathrm{C}-\mathrm{H} / \mathrm{C}-\mathrm{D}$ and $\mathrm{C}-\mathrm{H} / \mathrm{C}$ - $\mathrm{T}$ kinetic isotope effects.

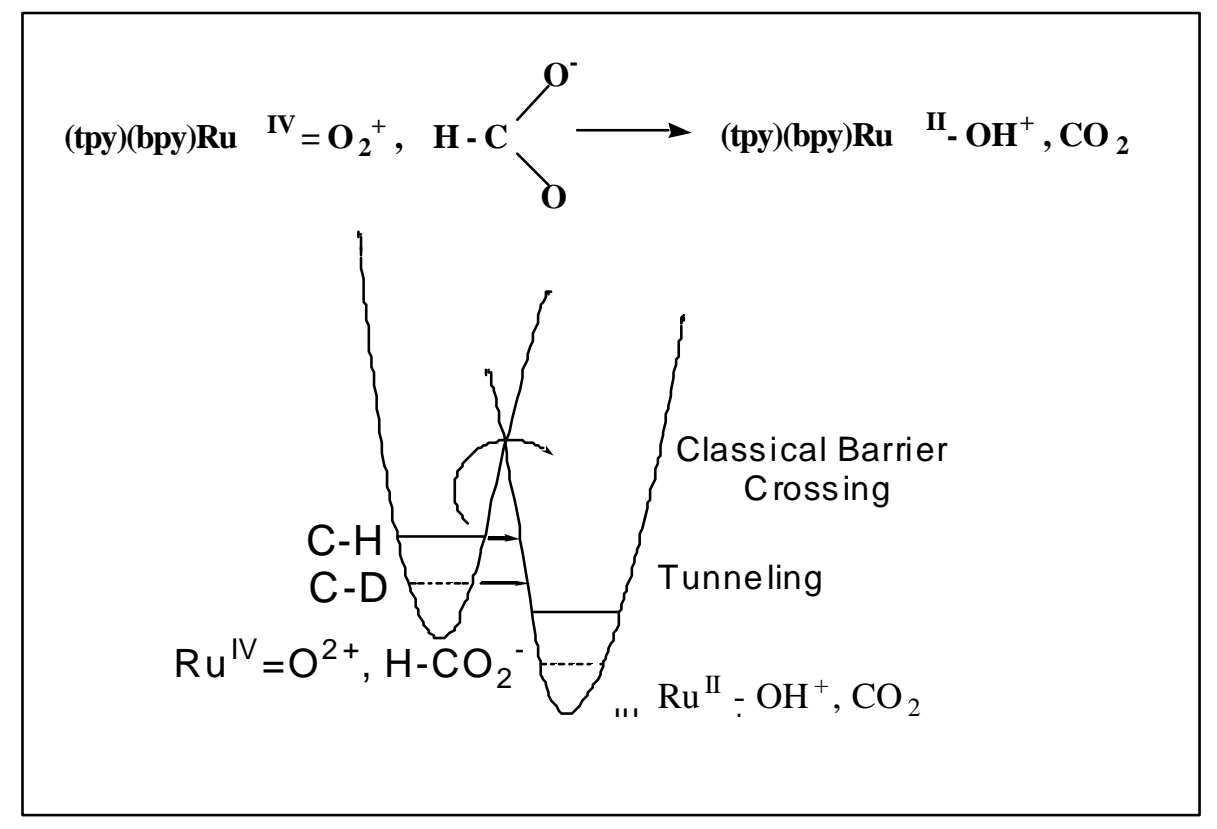

Figure 1. Potential energy configuration coordinate diagram for the hydride transfer reaction

Reduction of Carbon Dioxide to Formate. The formate anion is an attractive substrate for a "cold" demonstration involving the removal of deuterium from water because the formate anion can be separated by ion exchange from the reaction mixture. In order to create a closed electrolysis cycle, it would be advantageous to reduce $\mathrm{CO}_{2}$ to formate. We have investigated the electrochemical reduction of $\mathrm{CO}_{2}$ to formate, equation 1. This is an important reaction because deuterium or tritium from water is incorporated into the formate anion product by electrolysis.

$$
\mathrm{CO}_{2}+2 \mathrm{e}^{-}+\mathrm{H}^{+} \longrightarrow \mathrm{HCO}_{2}^{-}
$$

There are literature precedents for the electrochemical reduction of $\mathrm{CO}_{2}$. We have conducted a series of experiments at an activated indium electrode. Initial results gave current efficiencies of $\sim 70 \%$ at low formate conversions which decrease to $20 \%$ at long electrolysis times as higher concentrations of formate appear in the solution. The maximum concentration of formate achieved was $0.04 \mathrm{~mol} / \mathrm{L}$. These results are encouraging in the sense that they show that the cycle can be closed. An ultimate goal is to create a closed electrochemical cycle with reduction of $\mathrm{CO}_{2}$ at the cathode, coupled to $\mathrm{Ru}(\mathrm{IV})$ oxo catalyzed oxidation of formate at the anode. The net reaction produces concentrated tritium in the form of the tritiated formate anion. 

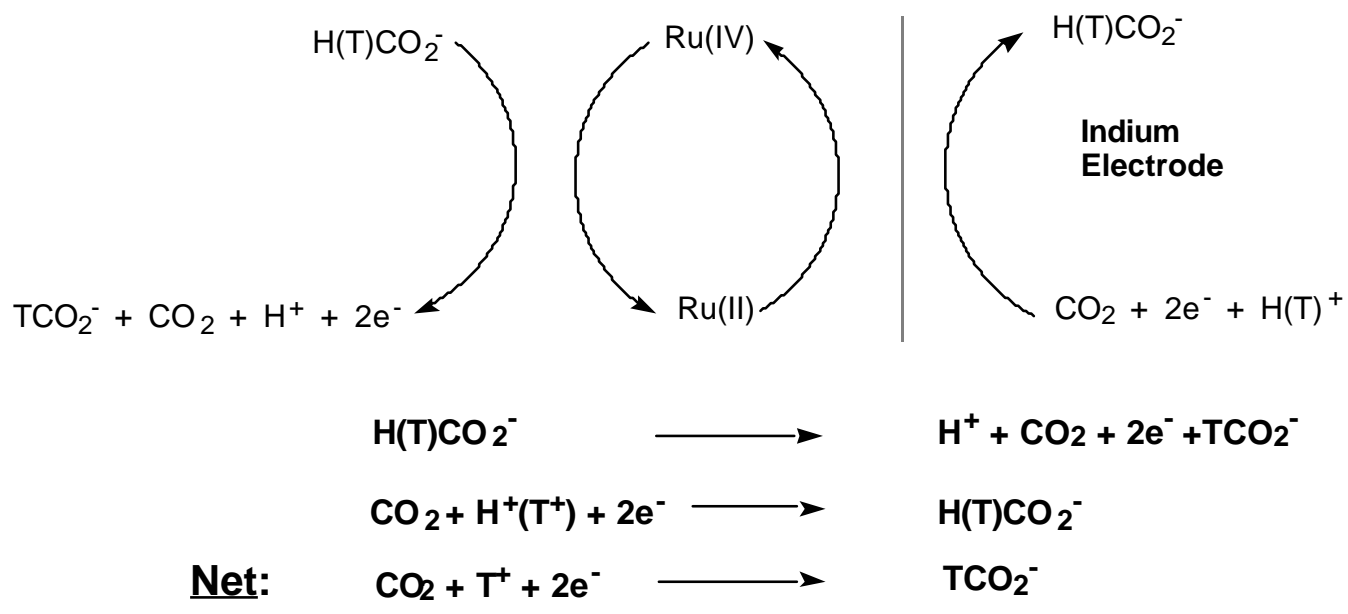

Electrochemical Fractionation of Protio- and Deutero-Formate. By observing the build up of deuterated formate in the catalyzed oxidation of a mixture of deutero and proteo-formate, a demonstration of the fractionation of deuterium was completed as a proof of principal. The results of the study demonstrated that kinetic isotope effects and formate oxidation can be used to achieve isotopic separation. The approach that we took exploited the fact that in an isotopic mixture, the oxidation of the protio form is far more rapid than the deuterio form.

Electrochemical oxidation of a mixture of protio and deuterio forms with $\mathrm{Ru}^{\mathrm{IV}}=\mathrm{O}^{2+} / \mathrm{Ru}^{\mathrm{II}}-\mathrm{OH}_{2}{ }^{2+}$ as the catalyst couple results in preferential oxidation of the $\mathrm{C}-\mathrm{H}$ forms over the $\mathrm{C}-\mathrm{D}$ form. This enriches the heavier isotope and permits the recovery of the concentrated product by a suitable separation method.

In a typical experiment, the related oxidant $[\mathrm{Ru}(\mathrm{tpy})(\mathrm{bpy})(\mathrm{O})]^{2+}$ (tpy is $2,2^{\prime}, 6^{\prime}$ 'terpyridine; bpy is 2,2'- bipyridine) was generated electrochemically from $\left[\mathrm{Ru}(\mathrm{tpy})(\mathrm{bpy})\left(\mathrm{H}_{2} \mathrm{O}\right)\right]^{2+}$ by holding the potential of an electrode at $0.8 \mathrm{~V} v s \mathrm{SSCE}$ (saturated sodium chloride electrode) at $\mathrm{pH}=6$ in $1.0 \mathrm{M}$ ionic strength $\mathrm{NaClO}_{4}$ or $\mathrm{Na}_{2} \mathrm{SO}_{4}$. Once generated, $\mathrm{Ru}^{\mathrm{IV}}=\mathrm{O}^{2+}$ oxidizes formate anion to $\mathrm{CO}_{2}$ as previously shown. In this experiment conducted by using a potentiostat, hydrogen is generated at a platinum counter electrode. The net reaction in the cell is as shown in equation (2)

$$
\mathrm{HCO}_{2}^{-}+\mathrm{H}^{+} \longrightarrow \mathrm{H}_{2}+\mathrm{CO}_{2}
$$

The electrolysis experiments were conducted at varying initial ratios of $\mathrm{HCO}_{2}{ }^{-}$and $\mathrm{DCO}_{2}{ }^{-}$ and for different electrolysis times. The current-time profiles were integrated to determine the total coulombs passed, $\mathrm{Q}$ in coulombs (C), and from it the extent of electrolysis, $\mathrm{F}_{\mathrm{el}}$, by the 
relationship in equation (7). In this equation, $\mathrm{F}$ is the Faraday constant $\left(=96,500 \mathrm{C} \mathrm{mol}^{-1}\right), \mathrm{n}$ is the number of electrons passed per equivalent $(n=2), V$ is the solution volume in liters and $\left[\mathrm{HCO}_{2}^{-}\right]_{\mathrm{tot}}$ is the total initial formate anion concentration.

At the end of the electrolysis period the solutions were evaporated to dryness and the

$$
\mathrm{F}_{\mathrm{el}}=\frac{\mathrm{Q} / \mathrm{nFV}}{\left[\mathrm{HCO}_{2}^{-}\right]_{\mathrm{tot}}}
$$

amounts of unreacted $\mathrm{HCO}_{2} \mathrm{Na}$ and $\mathrm{DCO}_{2} \mathrm{Na}$ in the isotopic mixture determined by infrared spectroscopy (IR). In these measurements, relative peak areas for the $v(C-H)$ and $v(C-D)$ stretching bands at $2834 \mathrm{~cm}^{-1}$ and $2134 \mathrm{~cm}^{-1}$ were measured in solid state IR spectra in $\mathrm{KBr}$ films. The amounts of $\mathrm{HCO}_{2} \mathrm{Na} / \mathrm{DCO}_{2} \mathrm{Na}$ were determined from calibration curves.

Table 1. Mole fraction of $\mathrm{DCO}_{2}{ }^{-}$as a function of electrolysis time

\begin{tabular}{|c|c|c|}
\hline $\begin{array}{c}\mathrm{D} /(\mathrm{H}+\mathrm{D}) \text { before } \\
\text { Electrolysis }\end{array}$ & $\begin{array}{c}\text { \% electrolyzed based on } \\
\text { number of coulombs passed } \\
\text { during electrolysis }\end{array}$ & $\begin{array}{c}\mathrm{D} /(\mathrm{H}+\mathrm{D}) \text { after } \\
\text { Electrolysis }\end{array}$ \\
\hline .41 & 28 & .72 \\
\hline .41 & 9 & .43 \\
\hline .57 & 29 & .80 \\
\hline .57 & 59 & .91 \\
\hline .50 & 28 & .61 \\
\hline .73 & 35 & .99 \\
\hline
\end{tabular}

In Table 1 are given the changes in mole fraction of $\left[\mathrm{DCO}_{2}^{-}\right]$in $\left[\mathrm{DCO}_{2}{ }^{-}\right] /\left[\mathrm{HCO}_{2}{ }^{-}\right]$ mixtures from before, $\mathrm{F}_{\mathrm{o}}$, to after electrolysis was complete, $\mathrm{F}_{\mathrm{f}}$. For example, starting with $\mathrm{F}_{\mathrm{o}}=$ 0.41, $\left(\left[\mathrm{DCO}_{2}{ }^{-}\right]+\left[\mathrm{HCO}_{2}{ }^{-}\right]=29.3 \mathrm{mM}\right)$, and $28 \%$ electrolysis, the fraction of $\mathrm{DCO}_{2}{ }^{-}$in the unreacted sample was $F_{f}=0.72$. In the IR analysis of the formate mixture, only $\mathrm{HCO}_{2} \mathrm{Na}$ could be accurately determined by infrared spectroscopy only at low concentrations because of the overlap of $v_{C-D}$ with overtone bands at 2134 and $1514 \mathrm{~cm}^{-1}$. It was also not possible to determine $\mathrm{DCO}_{2} \mathrm{Na}$ as $\mathrm{DCO}_{2} \mathrm{H}$ after acidification by GC-MS because of overlap of the parent ion peak at $\mathrm{m} / \mathrm{z}=46$ with $\mathrm{m} / \mathrm{z}-1$ peak of $\mathrm{HCO}_{2}{ }^{-}$as well as large background problems arising from the large excess of the supporting electrolyte. Consequently results in Table 1 were obtained in mixed samples at relatively high $\mathrm{F}_{\mathrm{o}}$ in order to use the IR analysis. 
We have been able to show that the amount of deuterated formate remaining in solution following electrolysis is given by the equation:

$$
\frac{\left[\mathrm{DCOO}^{-}\right]}{\left[\mathrm{DCOO}{ }^{-}\right]_{0}}=\left\{\frac{\left(\left[\mathrm{HCOO}{ }^{-}\right]_{0}-I_{S S} t / n F V\right)}{\left[\mathrm{HCOO}^{-}\right]_{0}}\right\}^{\frac{k_{D}}{k_{H}}}
$$

where $\mathrm{k}_{\mathrm{D}} / \mathrm{k}_{\mathrm{H}}$ is the deuterium kinetic isotope effect, $\mathrm{I}_{\mathrm{ss}}$ is the stationary state current, $\mathrm{t}$ is the time, $\mathrm{F}$ is Faradays constant and $\mathrm{V}$ is the volume of solution.

The results obtained demonstrate that it is possible to use an electrocatalytic procedure to achieve preferential oxidation of $\mathrm{C}$-H over $\mathrm{C}$-D in formate anion to achieve significant enrichment of the heavier isotope in a single electrolysis stage. By extrapolation, even more efficient concentration of tritium should be possible in $\mathrm{HCO}_{2}{ }^{-}, \mathrm{DCO}_{2}{ }^{-}, \mathrm{TCO}_{2}{ }^{-}$mixtures given the $\mathrm{k}_{\mathrm{H}} / \mathrm{k}_{\mathrm{T}}$ ratio of 305 .

Kinetic Isotope Effects For Oxidation of Target Organic Substrates. Because of technical difficulties in a practical device arising from reduction of $\mathrm{CO}_{2}$, it is important for us to broaden the base of carrier molecules. Earlier work had shown that an even higher deuterium kinetic isotope effect of $>60$ was observed for oxidation of benzyl alcohol by a related Ru-oxo oxidant. Benzyl alcohol derivatives are potentially attractive for a catalytic cycle. Electrochemical reduction of the benzyl alcohol oxidation product (aldehyde or ketone) would then be the reductive half cycle in which tritium is incorporated in the substrate. Our preliminary investigation of electrochemical reduction of benzophenone indicated that the corresponding pinacol was the principal product. ${ }^{20}$ The pinacol is the product that results from coupling of radical intermediates. An alternative reduction half reaction is hydrogen evolution followed by hydrogenation of the organic substrate. Low temperature, low pressure hydrogenation of the corresponding ketone (benzophenone) will be the method of incorporation of the hydrogen isotopes. Electrochemical reduction of the tritium-contaminated water (mixture of $\mathrm{T}_{2} \mathrm{O}, \mathrm{HTO}$, $\mathrm{H}_{2} \mathrm{O}$, HDO and $\mathrm{H}_{2} \mathrm{O}$ ) under suitable $\mathrm{pH}$ conditions to $\mathrm{T}_{2}, \mathrm{HT}, \mathrm{D}_{2}, \mathrm{HD}$ and $\mathrm{H}_{2}$ (g) and incorporation of tritium into the organic substrate will be a satisfactory alternative. For example, the reduction of benzaldehyde (or acetophenone) to benzyl alcohol (or sec-phenethanol) can be accomplished over a palladium catalyst (eq.5) at ambient temperature and pressure.

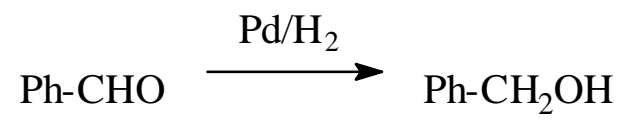

Detailed kinetic studies will be required to screen new oxidants and potential carriers and to establish mechanistic details required to develop successful catalytic cycles. Preleminary studies of the oxidation of some benzyl alcohol derivatives was carried out. 
The kinetic isotope effect for oxidation of singly deuterated benzyl alcohol, $\mathrm{C}_{6} \mathrm{H}_{5} \mathrm{C}(\mathrm{H})(\mathrm{D}) \mathrm{OH}$, by $\mathrm{Ru}(\mathrm{IV})($ tpy $)($ bpy $)(\mathrm{O})^{2+}$ is only 3.9. This is apparently due to selective and preferential oxidation of $\mathrm{C}-\mathrm{H}$ over $\mathrm{C}-\mathrm{D}$. The observed rate constant data are given below

$$
\begin{array}{cll}
\mathrm{Ru}(\mathrm{IV})(\mathrm{tpy})(\mathrm{bpy})(\mathrm{O})^{2+}+\mathrm{PhCH}_{2} \mathrm{OH} & \longrightarrow \mathrm{k}=11.9 \mathrm{M}^{-1} \mathrm{sec}^{-} \\
\mathrm{Ru}(\mathrm{IV})(\mathrm{tpy})(\mathrm{bpy})(\mathrm{O})^{2+}+\mathrm{PhCH}(\mathrm{D}) \mathrm{OH} & \longrightarrow \mathrm{k}=3.05 \mathrm{M}^{-1} \mathrm{sec}^{-1} \\
\mathrm{Ru}(\mathrm{IV})(\mathrm{tpy})(\mathrm{bpy})(\mathrm{O})^{2+}+\mathrm{PhCD}_{2} \mathrm{OH} & \longrightarrow \mathrm{k}=0.229 \mathrm{M}^{-1} \mathrm{sec}^{-1} \\
\mathrm{Ru}(\mathrm{IV})(\mathrm{tpy})(\mathrm{bpy})(\mathrm{O})^{2+}+\mathrm{PhCD}\left(\mathrm{CH}_{3}\right) \mathrm{OH} & \longrightarrow \mathrm{k}=0.356 \mathrm{M}^{-1} \mathrm{sec}^{-1}
\end{array}
$$

This was an important experiment since incorporation of tritium in the substrate would be at a level that there would never be more than one tritium per molecule. Catalyzed oxidation would always occur at the $\mathrm{C}-\mathrm{H}$ bond rather than at the $\mathrm{C}-\mathrm{T}$ bond. These results reveal the importance of designing a "single site" carrier molecule to realize the large isotope effects.

Chemically Modified Electrodes. The development of a practical tritium removal system based on the catalyzed oxidation of an organic compound may not be possible based on a soluble catalyst because of the difficulties in catalyst recovery. This limitation can be overcome by confining the catalyst to the surface of the electrode. A preliminary report of the mechanism of the proton coupled electron transfer reactions on a surface modified electrode has been published. $^{21}$ Studies have been conducted of an ITO $\left(\mathrm{In}_{2} \mathrm{O}_{3}: \mathrm{Sn}\right)$ electrode coated with $\mathrm{TiO}_{2}$ and the ruthenium complex $\mathrm{Ru}$ (terpy)( $\left(4,4^{-}-\left(\mathrm{PO}_{3} \mathrm{H}_{2}\right)\right.$ bpy) $\left(\mathrm{H}_{2} \mathrm{O}\right)^{2+}$ As shown in the figure at the right, stable surface structures are created by binding of phosphonate groups to metal oxide substrates.

We have investigated the electrochemical kinetics of the $\mathrm{Ru}(\mathrm{III}) / \mathrm{Ru}(\mathrm{IV})$ redox couple by using cyclic voltammetry and utilizing this chemically modified electrode. Previous results have shown that it is very difficult to observe the III/IV redox couple on metallic or even glassy carbon electrodes because of slow electron transfer kinetics at the surface. With an ITO electrode coated with $\mathrm{TiO}_{2}$ and $\mathrm{Ru}($ terpy $)\left(\left(4,4^{-}-\left(\mathrm{PO}_{3} \mathrm{H}_{2}\right)\right.\right.$-bpy $)\left(\mathrm{H}_{2} \mathrm{O}\right)^{2+}$, enhanced response of the III/IV redox wave for $\mathrm{Ru}($ terpy $)(\mathrm{bpy})\left(\mathrm{H}_{2} \mathrm{O}\right)^{2+}$ dissolved in solution was observed (see figure on next page). ITO electrodes coated with $\mathrm{TiO}_{2}$ and $\left[\mathrm{Ru}(\mathrm{IV})(\right.$ terpy)$)\left(\left(4,4^{-}-\right.\right.$ $\left.\mathrm{PO}_{3} \mathrm{H}_{2}\right)$ bpy)O$]^{2+}$ have also been used to study the catalyzed oxidation of benzyl alcohol to benzaldehyde. These experiments show that the reactivity of the solution catalyst can be translated to a surface modified electrode. 
Conclusions and Prognosis for a Practical System. Considerable progress has been made toward demonstrating the individual steps required for the concentration of tritium in water. An extremely large tritium kinetic isotope effect was observed for the oxidation of formate by a $\mathrm{Ru}(\mathrm{IV})$ oxo catalyst, and this result is significant for both scientific and technological reasons. Fractionation of deuterium in a mixture of protio- and deutero-formate was observed in the catalyzed electrochemical oxidation. Carbon dioxide can be reduced to formate in an electrochemical process, allowing a catalytic cycle to be designed. Chemically modified electrodes were prepared, and reactivities analogous to that found for solution species was observed. A new family of Os-based oxidants which display large H/D kinetic isotope effects was developed.

Nonetheless there are a number of problems that must be solved before a practical process can be tested. The amounts of formate that can be generated in a direct electrochemical reaction are not large enough to be particularly useful if the process is to be carried out in only a few stages. Sluggishness in the electrochemically driven oxidation of formate can be improved by employing a catalyst that has reduced stability at the $\mathrm{Ru}(\mathrm{III})$ oxidation state. Practical electrochemical cells which combine both the oxidation and reduction half reactions must be designed and tested. These and other questions will be addressed in the research plan.

\section{Relevance, Impact, and Technology Transfer}

Radioactive and mixed waste containing tritium continues to be a problem for which a satisfactory solution has not been devised. The existing technology for tritium removal from water is not cost effective. Tritium has a relatively short half-life (12.4 yr), decaying by the emission of a low energy $\beta$ particle $(5.7 \mathrm{keV})$. Tritium is generally present in contaminated water as HTO, where one of the hydrogen isotopes is replaced by a tritium, and as such the tritium $(\mathrm{T})$ exchanges rapidly with protium $(\mathrm{H})$ allowing it to move with water. A process to remove tritium from contaminated water should result in water which meets the maximum contaminant limit $(\mathrm{MCL}-20 \mathrm{pCi} / \mathrm{mL}$ or $0.02 \mu \mathrm{Ci} / \mathrm{L})$. There are a number of DOE sites in which tritium contamination in storage pools, ground water, or process waste is a problem. A large percentage of the radioactivity released to surface water at DOE's Savannah River Site is tritium. The Savannah River Site was the principal US production site for tritium for the weapons program. STCG need number SR00-3016 (priority 1) calls for tritium hydrogeological control and /or treatment technologies where a cost effective means of reducing the tritium concentration from 4 to $300 \mu \mathrm{Ci} / \mathrm{L}$ to the MCL is desired. The current technology is to pump and reinject upgradient until the tritium has decayed to an acceptable level. In addition to groundwater plumes contaminated with tritium, there are substantial quantities of tritiated water in reactor basins. Need statement SR00-4014 calls for technology to remove tritium from contaminated water in reactor basins. In this case it is desirable to get the level down to the point that the water can be released to the surface. 
The DOE Hanford Site was the location of the main production reactors for plutonium generation, and tritium is a problem in the $\mathrm{K}$-Basin and $\mathrm{N}$-Basin used for fuel storage. The water became contaminated with tritium from leaking fuel rod assemblies. The K-East Basin contains a million gallons of contaminated water with a tritium concentration of 2 to $3 \mu \mathrm{Ci} / \mathrm{L}$. The Richland Operations Office STCG need RL-MW023 indicates there is no currently identified technology capable of solving the site's problems.

Idaho National Engineering Laboratory also has water filled nuclear fuel storage basins containing tritiated water. Smaller, but nonetheless significant, problems with tritium contamination exist at the DOE Mound Laboratory, at DOE's Oak Ridge Site, and at other DOE national laboratories (Los Alamos, Argonne, Lawrence Berkeley, and Brookhaven). The STCG at the DOE Oakland Operations Office has several high priority needs for tritium removal (OAK-003 and OK99-13). There are also nuclear fuel storage systems at private utility sites where the need to remove tritium from contaminated water exists.

Tritium separation technology and tritium mitigation techniques are reviewed biennially as applied to Hanford wastewater as mandated by the Hanford Federal Facility Agreement and Concent Order. Reports issued in $1995^{22}, 1997^{23}$, and $1999^{24}$ all indicate that there are no commercial processes in operation today that are capable of reducing the tritium concentration from $10 \mu \mathrm{Ci} / \mathrm{L}$ to the MCL of $0.02 \mu \mathrm{Ci} / \mathrm{L}$. Fulbright, et $\mathrm{al}^{25}$ have reviewed the available technology with respect to the needs for tritium removal at Savannah River, and recommendations were for further investigation of several technologies. The baseline technology at the Savannah River Site is pump and upgradient reinjection. Among the more attractive technologies for controlling tritium in groundwater at the present time are mitigation technologies. One such technique is pumping and upgradient reinjection. A variation of this is to store the water in a carbon steel or stainless steel tank. Fulbright, et al found this to be a surprisingly economical solution. Barrier formation, in which the source of the contamination can be blocked by a simple and well-established method such as ground freezing, has been suggested. This is a well-established civil engineering method to maintain water entry control to an area. Holes are drilled in the area and refrigerant is circulated, freezing the soil to prevent migration of ground water either into or out of the site. This method may be effective for the short-term control of an isolated site with a well defined source of contamination. However a method for the direct remediation of ground water contaminated by tritium would be preferable. The Oak Ridge Problem originates from leakage at burial grounds for radioactive waste. Water flowing through the burial site picks up tritium and carries it ultimately to the Clinch River. Air sparging is a simple method of removing the tritium from the groundwater, but by necessity, the HTO vapor is discharged to the atmosphere. Phytoremediation is a subset of evaporation in which transpiration of water through the leaves of a plant or tree takes contaminated water from the liquid phase to the vapor phase (with high dilution). These latter mitigation methods which release tritium to the atmosphere are unlikely to be found acceptable by the public. 
The majority of the methods that have been reported for actual tritium separation have as their objective the economical concentration of $\mathrm{T}$ with respect to $\mathrm{H}$ (or D) from either water or the elemental gas. The solution to DOE's contamination problems involves a different objective, the removal of the tritium to a form that cannot exchange rapidly with ground water thus allowing discharge of the remediated water to the surface. There appear to be no good methods to separate tritium on a small scale that leaves it in a form that does not rapidly exchange with protio-compounds in the environment.

Highly concentrated tritiated water is an extreme health hazard, given the rapid rate of exchange with protio-water. Any accidental release of highly enriched material would be an enormous health risk. The design of a cost effective separation process that would leave the tritium in a form that does not exchange rapidly with water and that could be applied on a variety of scales would be of great benefit to DOE's Environmental Management and Waste Remediation Program. One of the strengths of our methodology is that tritium is incorporated into a non-exchangeable form as a natural consequence of the separation process. Thus the remediation process itself and the generation of a suitable waste form can be combined in an integrated process.

\section{Project Productivity:}

This project had good scientific productivity as evidenced by the record of publications and presentations. Several papers are being drafted and will be submitted shortly. Determination of a kinetic isotope effect of $>300$ is an outstanding accomplishment, representing the largest kinetic isotope effect ever measured at ambient temperature in fluid solution.

The chemistry for the oxidative half cycle for a scheme for isotope separation based on kinetic isotope effects was demonstrated. We were not able to realize a bench scale process to enrich deuterium from water because of difficulty in the reductive half cycle. Further work will be needed to resolve these issues.

\section{Personnel Supported:}

Professional personnel supported by the research effort:

Gilbert M. Brown, C.-H. Ho, Leon Maya, Bruce A. Moyer, and Frederick V. Sloop, Jr, Chemical and Analytical Sciences Division, Oak Ridge National Laboratory.

Thomas J. Meyer, University of North Carolina at Chapel Hill

Postdoctoral Fellows supported by the research effort: 
Poonam M. Narula and My Hang V. Huynh, Department of Chemistry, University of North Carolina at Chapel Hill

\section{Peer Reviewed Publications}

Mechanisms of Surface Electron Transfer. Proton-Coupled Electron Transfer. Trammell, S. A.; Wimbish, J. C.; Odobel, F.; Gallagher, L. A.; Narula, P. M.; Meyer, T. J. J. Am. Chem. Soc. 1998, 120, 13248-13249.

Oxo-Like Reactivity of High Oxidation State Osmium Hydrazido Complexes. Huynh, M. H. V.; El-Samanody, E.; Demadis, K. D.; Meyer, T. J.; White, P.S. J. Am. Chem. Soc., 1999, 121, 1403-1404.

The Effect of Stepwise Oxidation on Molecular Structure in Osmium Hydrazido Complexes. Huynh, M. H. V.; El-Samonody, E-S.; Meyer, T. J.; White, P. S., Inorg Chem., 1999, 38, 3760.

Proton-Coupled Electron Transfer from Nitrogen. A N-H/N-D Kinetic Isotope Effect of 41.4. Huynh, M. H. V.; White, P. S.; Meyer, T. J. J Amer Chem Soc., 1999, 121, 4530-4531.

Intramolecular Oxidative Substitution on Coordinated Terpyridyl Ligand. Huynh, M. H. V.; Lee, D. G.; Meyer, T. J.; White, P. S., J Amer Chem Soc., 1999, 121, 10446-10447.

Plasma Assisted Reduction of Carbon Dioxide in the Gas Phase, Maya, L., J. Vac. Sci. Technol. A, 2000, 18, 285-287.

Surface Catalysis of Solution Electron Transfer. Narula;P. M.; Trammell, S. A.; Meyer, T. J., in preparation.

Reduction of Benzoquinone by trans-[OsIV(tpy) $(\mathrm{Cl}) 2(\mathrm{~N}(\mathrm{H}) \mathrm{N}(\mathrm{CH} 2) 4 \mathrm{O})](\mathrm{PF} 6)$. Proton-Coupled Electron Transfer from Nitrogen. Huynh, M. H. V,. Meyer, T. J., in preparation.

H/D Isotope Separation based on Kinetic Isotope Effects, P. M. Narula, F. V. Sloop, G. M. Brown, L Maya, and T. J. Meyer, in preparation.

Deuterium and Tritium Kinetic Isotope Effects for the Oxidation of Formate by (Terpyridine)(bipyridine)(oxo)ruthenium(IV), G. M. Brown, F. V. Sloop,Jr., B. A. Moyer, and T. J. Meyer, in preparation.

Kinetic Isotope Effects for the Oxidation of Benzyl Alcohol Derivatives by (Terpyridine)(bipyridine)(oxo)ruthenium(IV), G. M. Brown, F. V. Sloop,Jr., C.-H. Ho, and T. J. Meyer, in preparation.

\section{Interactions}

The PI participated in two EMSP workshops with the presentation of detailed posters describing the progress made in this project (Chicago, 1998 and Atlanta, 2000). The PI participated in an 
additional EMSP workshop in Oak Ridge in 1999 (USDOE Oak Ridge Operations Environmental Management Science Program Workshop, Oak Ridge, TN, Sept. 22, 1999) . The PI was invited to make a presentation at a symposium featuring the first results from the EMSP at the $218^{\text {th }}$ National Meeting of the American Chemical Society in New Orleans, 1999. The PI was approached by the chairman of the Site Technology Coordinating group at DOE's Oakland Office, Joe Wong, with an interest in our technology. Tritium in groundwater is one of the main concerns at DOE-Oakland. As a result of this interaction, the PI made a presentation at a meeting of the Oakland site Technology Coordinating Group in July, 1999. Brookhaven National Laboratory has had problems with tritium leaking from its reactor, and the PI was invited to present a seminar at the Chemistry Department at BNL by the Chairman of the Department, Carol Creutz.

Presentations from This Research Program:

G. M. Brown, C.-H. Ho, L. Maya, F. V. Sloop, Jr, P. M. Narula and T. J. Meyer "Concentration of Tritium and Deuterium Based on Large Primary Kinetic Isotope Effects in Catalytic Redox Processes," Symposium in honor of the $60^{\text {th }}$ birthday of Thomas J. Meyer, Santa Fe, NM, May $17,2001$.

G. M. Brown, P. M. Narula, F. V. Sloop, and T. J. Meyer, "Electrocatalytic Enrichment of Isotopes of Hydrogen in Protio- and Deuterio-Formate in Oxidation Reactions," 218th American Chemical Society National Meeting, New Orleans, LA, Aug. 22-24, 1999.

G. M. Brown, C.-H. Ho, L. Maya, B. A. Moyer, F. V. Sloop, P. M. Narula, and T. J. Meyer, "Utilization of Kinetic Isotope Effects for the Concentration of Tritium," USDOE Site Technology Coordination Group, DOE Oakland Office, Oakland, CA, July 13, 1999.

G. M. Brown, C.-H. Ho, P. M. Narula, L. Maya, T. J. Meyer, B. A. Moyer, and F. V. Sloop, "Concentration of Tritium Based on Large Primary Kinetic Isotope Effects in Catalytic Redox Processes," Brookhaven National Laboratory, June 23, 1999.

G. M. Brown, F. V. Sloop, Jr., B. A. Moyer, and T. J. Meyer, "Deuterium and Tritium Kinetic Isotope Effects for the Oxidation of Formate by Ruthenium(IV) Oxo Compounds," 216th American Chemical Society National Meeting, Boston, MA, Aug. 23-27, 1998.

In August, 1997 the PI attended a symposium on Innovative Technologies for Tritium at the TIE Workshop sponsored by the Subsurface Contaminants Focus Area. This meeting brought together the leaders in the field as well as members of the Efficient Separation and Processing Crosscutting Focus Area. This meeting gave the PI a good understanding of the practical problems to be encountered in processing tritium contaminated groundwater. 


\section{Transitions}

In the present state of development, this technology is not ready for a field demonstration. Duke Power Corporation, working with the University of North Carolina, expressed interest in this technology as a possible means of removing tritium from cooling water pools at its reactor sites. As a result of this interaction, the University for North Carolina filed for patent protection.

\section{Patents and Invention Disclosures:}

The technology was disclosed to DOE in July 1998, prior to the first EMSP workshop. ORNL and DOE decided not to pursue patent protection.

On July 27, 1999, The University of North Carolina filed U.S. Patent application serial no. 09/361,712 "Concentration and removal of Tritium and/or Duterium from Water Contaminated with Tritium and/or Deuterium." The patent has been allowed and should issue shortly.

\section{Future Work:}

One of the problems encountered in the catalyzed oxidation of formate by $\mathrm{Ru}(\mathrm{IV})(\mathrm{tpy})(\mathrm{bpy})(\mathrm{O})^{2+}$ is that the oxidation of $\mathrm{Ru}$ (II) species to $\mathrm{Ru}(\mathrm{IV})$ proceeds in a step-wise manner through $\mathrm{Ru}(\mathrm{III})$ intermediate. The direct oxidation of the $\mathrm{Ru}(\mathrm{III})$ species is sluggish. The actual mechanism at the electrode is disproportionation of the $\mathrm{Ru}(\mathrm{III})$ species followed by oxidation of $\mathrm{Ru}(\mathrm{II})$ to $\mathrm{Ru}(\mathrm{III})$ (equation 5).

$$
\begin{array}{r}
2 \mathrm{Ru}(\mathrm{III})(\mathrm{tpy})(\mathrm{bpy})(\mathrm{OH})^{2+} \longrightarrow \mathrm{Ru}(\mathrm{IV})(\mathrm{tpy})(\mathrm{bpy})(\mathrm{O})^{2+}+\mathrm{Ru}(\mathrm{II})(\mathrm{tpy})(\mathrm{bpy})\left(\mathrm{OH}_{2}\right)^{2+} \\
\mathrm{Ru}(\mathrm{II})(\mathrm{tpy})(\mathrm{bpy})\left(\mathrm{OH}_{2}\right)^{2+} \longrightarrow \mathrm{Ru}(\mathrm{III})(\mathrm{tpy})(\mathrm{bpy})(\mathrm{OH})^{2+}+\mathrm{H}^{+}+\mathrm{e}^{-}(5 \mathrm{~b})
\end{array}
$$

With changes in the electronic nature of substituents on the bpy ligand, the $\mathrm{Ru}(\mathrm{III})$ couple in $\mathrm{Ru}($ tpy)( $\mathrm{LL})\left(\mathrm{H}_{2} \mathrm{O}\right)^{2+}$ complexes is unstable with respect to disproportionation and direct. oxidation of $\mathrm{Ru}(\mathrm{II})$ to $\mathrm{Ru}(\mathrm{IV})$ occurs at the electrode. Where the ligand LL is 2,2'-bipyrazine (bpz), this effect has been documented by Gerli, et al. The $\mathrm{Ru}(\mathrm{II}) / \mathrm{Ru}(\mathrm{IV})$ redox potentials reveal that $\mathrm{Ru}(\mathrm{IV})(\mathrm{tpy})(\mathrm{bpz})(\mathrm{O})^{2+}$ is a slightly stronger oxidant than the corresponding bpy derivative. Kinetic measurements show that the rate of oxidation of benzyl alcohol is $50 \%$ faster than the bpy derivative, consistent with the potential measurements. A study to determine the deuterium kinetic isotope effects for oxidation of formate and sec-phenethanol by $\mathrm{Ru}(\mathrm{IV})(\operatorname{trpy})(\mathrm{bpz})(\mathrm{O})^{2+}$ will be rewarding. If these deuterium isotope effects are comparable to those previously observed, the analogous tritium kinetic isotope effects should be determined as well.

An additional area of promise in catalyst design is the evaluation of the redox couples of the $\mathrm{Ru}(\mathrm{VI}) / \mathrm{Ru}(\mathrm{IV})$ and $\mathrm{Ru}(\mathrm{IV}) / \mathrm{Ru}(\mathrm{II})$ couples of the dioxo reagent trans- $\left[\mathrm{Ru}(\operatorname{trpy}) \mathrm{O}_{2}\left(\mathrm{H}_{2} \mathrm{O}\right)^{2+}\right.$. 
The kinetics of benzyl alcohol oxidation by both couples has been investigated with the remarkable $\mathrm{k}_{\mathrm{H}} / \mathrm{k}_{\mathrm{D}}$ isotope effect of 63 observed for the $\mathrm{Ru}(\mathrm{IV}) / \mathrm{Ru}(\mathrm{II})$ couple in acetonitrile. Work with this couple should be extended to electrocatalysis on high surface area ITO/ $/ \mathrm{TiO}_{2}$ nanoparticle electrodes based on the phosphonated derivative, - $\left[\mathrm{Ru}\left(4^{\prime}-\mathrm{PO}_{3} \mathrm{H}_{2}\right.\right.$-trpy $)\left(\mathrm{H}_{2} \mathrm{O}\right)_{3}{ }^{2+}$. Electrochemical and spectral studies will indicate whether surface oxidation to the $\mathrm{Ru}(\mathrm{VI})$-transdioxo complex occurs, and if the high reactivity toward oxidation is retained.

\section{Literature Cited.}

1 “Tritium Isotope Separation,” G. Vasaru, CRC Press, Boca Raton, 1993.

${ }^{2}$ Allen, W. L. Tritiated Wastewater Treatment and Disposal Evaluations for 1995, 1995, DOE/RL-95-68, U.S. Department of Energy, Richland Operations, Richland, WA

3 Jeppeson, D. W., Biyani, R. K., Duncan, J. B., Evaluation of Technologies for Removal and Mitigation of Tritium in Hanford Wastewaters, 1997, DOE/RL-97-54, Rev 0, U.S. Department of Energy, Richland Operations Office, Richland, WA

4 Jeppeson, D. W., 1999 Evaluation of Tritium Removal and Mitigation Technologies for Wastewater Treatment, 1999, DOE/RL-99-42, Rev 0, U. S. Department of Energy, Richland Operations Office, Richland, WA.

5 Fulbright, H. H., Schwirian-Spann, A. L., Jerome, K. M., Looney, B. B., and Van Brunt, V., Status and Practicality of Detritiation and Tritium Reduction Strategies for Environmental Remediation, WSRC-RP-96-0075, Rev 0, Westinghouse Savannah River Company, Aiken, SC.

6 "Oxygen Transfer in the Oxidation of Triphenylphosphine by $\left[(\mathrm{bpy})_{2}(\mathrm{py}) \mathrm{Ru}(\mathrm{O})\right]^{2+",}$ Moyer, B. A.; Sipe, B. K.; Meyer, T. J. Inorg. Chem. 1981, 20, 1475.

7 "Oxygen Atom Transfer in the Oxidations of Dimethyl Sulfide and Dimethyl Sulfoxide by $\left[(\text { bpy })_{2}(\text { py }) \operatorname{Ru}(\mathrm{O})\right]^{2+",}$ Roecker, L.; Dobson, J. C.; Vining, W. J.; Meyer, T. J. Inorg. Chem. 1987, 26, 779.

8 "Hydride Transfer in the Oxidation of Alcohols by $\left[(\mathrm{bpy})_{2}(\mathrm{py}) \mathrm{Ru}(\mathrm{O})\right]^{2+}$. A $k_{\mathrm{H}^{\prime}} / k_{\mathrm{D}} \mathrm{Kinetic}$ Isotope Effect of 50", Roecker, L.; Meyer, T. J. J. Am. Chem. Soc., 1987, 109, 746.

9 "Hydride Transfer In The Oxidation of Formate Ion by $\left[(\mathrm{bpy})_{2}(\mathrm{py}) \mathrm{Ru}(\mathrm{O})\right]^{2+",}$ Roecker, L.; Meyer, T. J. J. Am. Chem. Soc., 1986, 108, 4066. 
10 "Hydrogen Atom Transfer in the Oxidation of Hydrogen Peroxide by $\left[(\mathrm{bpy})_{2}(\mathrm{py}) \mathrm{Ru} \mathrm{IV}_{=} \mathrm{O}\right]^{2+}$ and by $\left[(\text { bpy })_{2}\left(\text { py)Ru }{ }^{\mathrm{III}}-\mathrm{OH}\right]^{2+"}\right.$, Gilbert, J.; Roecker, L. ; Meyer, T. J. Inorg. Chem., 1987, 26, 1126.

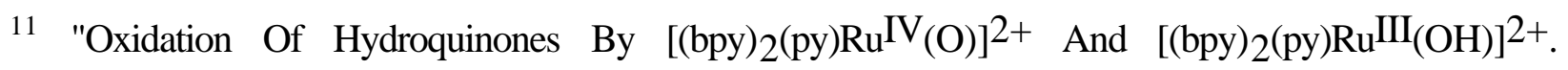
Proton Coupled Electron Transfer", Binstead, R. A.; McGuire, M. E.; Dovletoglou, A.; Soek, W. K.; Roecker, L.; Meyer, T. J. J. Am. Chem. Soc. 1992, 114, 173.

12 (a) "Preparation and Characterization of Stable Ruthenium(IV)-Oxo Complexes That Contain Tertiary Phosphine Ligands", Marmion, M. E.; Takeuchi, K. J. J. Am. Chem. Soc. 1986, 108, 510.

(b) "Oxo(phosphine)ruthenium(IV) Redox Chemistry: Substrate Oxidation Selectivity Based on Substrate Hydrophobicity", Marmion, M. E.; Takeuchi, K. J. J. Chem. Soc. Chem. Comm. 1987, 1396.

(c) "Ruthenium(IV)-Oxo Complexes: A Novel Hydrophobic Effect of Tertiary Phosphine Ligands on the Selective Oxidation of Alcohols", Marmion, M. E.; Takeuchi, K. J. J. Chem. Soc. Dalton Trans. 1988, 2385.

(d) "Ruthenium(IV)-Oxo Complexes: The Novel Utilization of Tertiary Pnictogen Ligands", Marmion, M. E.; Takeuchi, K. J. J. Am. Chem. Soc. 1988, 110, 1472.

13 (a) "High-Valent Ruthenium(IV) and -(VI) Oxo Complexes of Octaethylporphyrin. Synthesis, Spectroscopy, and Reactivities", Leung, W.-H.; Che, C.-M. J. Am. Chem. Soc. 1989, 111, 8812.

(b) "Kinetics of Alkene Oxidation by Cationic trans-Dioxo-ruthenium(VI) Complexes. Effect of Driving Force on Rate Constants", Che, C.-M; Li, C.-K.; Tang, W.-T.; Yu, W.-Y. J. Chem. Soc. Dalton Trans. 1992, 3153.

14 "H-Atom Transfer Between Metal Complex Ions In Solution", Binstead, R. A.; Meyer, T. J. J. Am. Chem. Soc., 1987, 109, 3287.

${ }^{15}$ See reference 8 .

16 "Novel Electrocatalytic Procedure for the Oxidation of Alcohols, Aldehydes, Cyclic Ketones, and C-H Bonds Adjacent to Olefinic or Aromatic Groups", Thompson, M.S.; De Giovani, W. F.; Moyer, B. A.; Meyer, T. J.J. Org. Chem., 1984, 49, 4972.

17 See reference 9.

18 Bell, R. P., Chem Soc. Rev, 1974, 3, 513. 
${ }^{19}$ Swain, G. C., Stivers, E. C., Reuwer, J. F., Schaad, L. J., J. Am. Chem. Soc., 1958, 80, 5885.

${ }^{20}$ C.-H. Ho and G. M. Brown, unpublished results.

${ }^{21}$ Mechanisms of Surface Electron Transfer. Proton-Coupled Electron Transfer. Trammell, S. A.; Wimbish, J. C.; Odobel, F.; Gallagher, L. A.; Narula, P. M.; Meyer, T. J. J. Am. Chem. Soc. 1998, 120, 13248-13249.

${ }^{22}$ Allen, W. L. Tritiated Wastewater Treatment and Disposal Evaluations for 1995, 1995, DOE/RL-95-68, U.S. Department of Energy, Richland Operations, Richland, WA

23 Jeppeson, D. W., Biyani, R. K., Duncan, J. B., Evaluation of Technologies for Removal and Mitigation of Tritium in Hanford Wastewaters, 1997, DOE/RL-97-54, Rev 0, U.S. Department of Energy, Richland Operations Office, Richland, WA

24 Jeppeson, D. W., 1999 Evaluation of Tritium Removal and Mitigation Technologies for Wastewater Treatment, 1999, DOE/RL-99-42, Rev 0, U. S. Department of Energy, Richland Operations Office, Richland, WA.

25 Fulbright, H. H., Schwirian-Spann, A. L., Jerome, K. M., Looney, B. B., and Van Brunt, V., Status and Practicality of Detritiation and Tritium Reduction Strategies for Environmental Remediation, WSRC-RP-96-0075, Rev 0, Westinghouse Savannah River Company, Aiken, SC. 